\title{
Effect of single Quercus ilex trees upon spatial and seasonal changes in soil water content in dehesas of central western Spain
}

\author{
Elena CUBERA, Gerardo MORENO* \\ Departamento de Biología y Producción de los Vegetales, Ingeniería Técnica Forestal, Universidad de Extremadura, Avenida Virgen del Puerto 2 , \\ 10600 Plasencia, Spain
}

(Received 30 May 2006; accepted 28 September 2006)

\begin{abstract}
The spatial and temporal evolution of soil water content $(\theta)$ in Quercus ilex dehesas has been investigated to determine how trees modify the soil water dynamics and the nature of tree-grass interactions in terms of soil water use in these ecosystems. Soil physical parameters and $\theta$ were measured at different distances from the tree trunk $(2-30 \mathrm{~m})$ in the upper $300 \mathrm{~cm}$ of soil. $\theta$ was measured monthly by TDR during $2002-2005$. Tree water potential was determined during the summers of 2004 and 2005. At deeper soil layers, mean $\theta$ values were higher beyond than beneath tree canopy during dry periods. $\theta$ depletion beyond tree canopy continued even in summer, when herbaceous plants dried up, suggesting that trees uptake water from the whole inter-tree space. Results have shown a high dependence of trees on deep water reserves throughout late spring and summer, which helps to avoid competition for water with herbaceous vegetation.
\end{abstract}

soil water content / TDR / Quercus ilex / oak woodland / tree-grass interaction

Résumé - Effets de chênes verts isolés sur les variations spatiales et temporelles de l'humidité du sol dans les dehesas du centre-ouest de l'Espagne. L'objectif de ce travail a été de déterminer les effets de chênes verts (Quercus ilex L.) isolés sur la teneur en eau du sol ( $\theta$ ) et la nature des interactions arbre-strate herbacée sous climat semi-aride, en terme d'utilisation de l'eau du sol dans ces écosystèmes. Les paramètres physiques du sol et $\theta$ ont été mesurés jusqu'à $300 \mathrm{~cm}$ de profondeur et à différentes distances $(2$ à $30 \mathrm{~m})$ autour des arbres. $\theta$ a été mesurée par TDR, mensuellement de 2002 à 2005 dans quatre dehesas. Le potentiel hydrique des arbres a été mesuré durant les étés 2004 et 2005. Essentiellement en profondeur et en été, les valeurs moyennes de $\theta$ furent plus élevées au-delà de la canopée que sous les arbres. La diminution de $\theta$ au-delà de la canopée des arbres a continué à diminuer encore en été lorsque les plantes herbacées étaient sèches, suggérant un prélèvement d'eau par les arbres. Nos résultats suggèrent alors que les arbres peuvent utiliser de l'eau localisée loin deux même à des distances de $20 \mathrm{~m}$. et qu'ils sont très dépendants des réserves d'eau en profondeur $(100-300 \mathrm{~cm})$ pendant la fin du printemps et en été, ce qui contribue à diminuer la concurrence pour l'eau entre arbres et strate herbacée.

contenu en eau du sol / TDR / Quercus ilex / chênaie / interaction arbre-herbacées

\section{INTRODUCTION}

Dehesas are characterized by the presence of a savannalike open tree stratum dominated by four Mediterranean oak species, Quercus ilex L., $Q$. suber L. (evergreen) and, to a lesser extent, $Q$. faginea Lam. (marcescent) and $Q$. pyrenaica Willd (deciduous). They are distinguished by a systematic combination of agricultural, pastoral and forestry uses. This peculiar system dominates the landscape of the south-western Iberian Peninsula [14], with 3100000 ha in the west and south-west of the Iberian Peninsula [7] and a tree density of 10-60 trees $\mathrm{ha}^{-1}$. The main characteristics defining Mediterranean ecosystems generally are the scarcity and irregularity of rainfall and evapotranspiration rates higher than the amount of precipitation [22,32]. Change patterns in soil water content with depth and over time, and the corresponding dry and wet cycles, are decisive factors in explaining species composition in a given area [2]. In this sense, Mediterranean evergreen oaks have been defined as 'regulators' in terms of water use [36],

* Corresponding author: gmoreno@unex.es and sensitive to water deficit and xylem embolism [25]. Indeed, episodic oak diebacks have been linked to periodical summer drought [32].

Studies carried out on silvopastoral systems have emphasised the importance of available water in determining the structure of the herbaceous and open-tree strata $[20,42]$. At the same time, vegetation strata affect each other through complex relationships that condition the amount of available water for each stratum. Trees can favour the pasture production through the improvement of soil physical and chemical fertility [33], but trees and pasture could compete for soil water. The positive effects of trees on soil physical properties include a higher soil water-holding capacity and macroporosity that is favourable to infiltration and redistribution of soil water beneath than beyond canopy cover $[19,34]$. This may explain therefore, the observed increases in soil water content under the dehesa tree cover found by these authors, compared to adjacent areas. These studies were conducted in subhumid climatic sites with about $700 \mathrm{~mm}$ of annual rainfall. As Joffre et al. [22] pointed out however, dehesas in drier conditions 
could respond differently, and until now, no research concerning the seasonal and spatial water distribution of $Q$. ilex trees in semi-arid conditions has been carried out. Studies conducted in North American oak savannas have found that frequently soil water content beneath oaks rarely differs from that in adjacent grasslands [27].

Tree clearance practiced in dehesas affects positively the development of the understory pasture, but also the single tree functioning. The spacing of trees in dehesas is advantageous in terms of water potential and $\mathrm{CO}_{2}$ assimilation rates at leaf and tree scale along the summer [16,28], compared to other holm-oak forest systems [39,40]. Joffre et al. [22] pointed out that the dehesa structure follows an ecohydrological equilibrium sensu Eagleson [8], who hypothesised that water limits natural vegetation systems, providing a canopy density that produces both minimum water stress and maximum biomass. The improved physiological status of dehesas trees could be explained by the increase in the soil volume exploited, and hence the availability of water and nutrients for each isolated tree. In fact, $Q$. ilex and $Q$. suber depends on the water located beyond tree cover in dehesas [20]. The importance of Quercus sp. to develop deep root systems for summer drought survival has been stressed by Canadell et al. [3]. The huge surface of soil explored by $Q$. ilex root system could allow trees to meet their water needs during the dry summers in dehesas [29].

The following questions were addressed: Where are trees taking water from during the summer drought? Do trees benefit of the low tree density? Do trees positively influence the soil water content? Are trees and grasses competing for soil water resources? To focus these questions our main objectives are (i) to determine the effects of isolated $Q$. ilex trees on both vertical and horizontal soil water content distribution, in semiarid conditions (ii) to study the seasonal patterns of soil water content in dehesas in order to characterise the pattern of water consumption of trees, particularly during the summer, and (iii) to determine the nature of tree-grass interactions in terms of water use.

\section{MATERIAL AND METHODS}

\subsection{Study area}

The study was conducted in four $Q$. ilex dehesas of central western Spain ( $39^{\circ} 41^{\prime} \mathrm{N}, 6^{\circ} 13^{\prime} \mathrm{W} ; 380 \mathrm{~m}$ a.s.1.). The climate is semi-arid Mediterranean, with a mean annual rainfall of $597 \mathrm{~mm}$, although this mainly falls from October to May. Mean minimum and maximum temperatures occur during January $\left(3.4{ }^{\circ} \mathrm{C}\right)$ and July $\left(35.5^{\circ} \mathrm{C}\right)$, respectively. The mean annual temperature is $16.2^{\circ} \mathrm{C}$, the mean annual potential evapotranspiration (PET), estimated by Thornthwaite [43], is $864 \mathrm{~mm}$, and there are dry, warm, and cold (with frost) periods of 4 , 3 , and 4 months, respectively. Climatic data of the study area belong to the nearby meteorological station (Cáceres, $39^{\circ} 28^{\prime} \mathrm{N}, 6^{\circ} 20^{\prime} \mathrm{W}$; $405 \mathrm{~m}$ a.s.1.). Soils are mainly Chromic Luvisols [18] developed over tertiary sediments which often comprise gravels and stones including clasts of quartzite. These strata typically contain one or more red argic horizons with a silty to sandy texture in the surface horizon and a sandier layer below $1 \mathrm{~m}$ in depth. In some areas where sediments were eroded, Eutric Leptosols are developed on schists, which outcrops locally (Tab. I). The vegetation was formed by herbaceous and tree canopy strata (Tab. I). In the four farms the herbaceous stratum comprised either cultivated cereals (oat and wheat) or native vegetation which is dominated by annual species such as Lolium rigidum Gaudin, Plantago lanceolata L., Erodium sp., Taraxacum obovatum (Willd.) DC., and Echium plantagineum L. Traditionally, dehesas were managed following a 4-year-cycle typical of these systems, 1 year cultivated, and 3 years grazed.

\subsection{Experimental layout}

The study was carried out in four experimental farms: Cerro Lobato $(C L)$, Baldío $(B A)$, Sotillo $(S T)$, and Dehesa Boyal $(D B)$, where soil water content $(\theta)$ was measured around $9,16,6$, and 6 trees, respectively. In each tree, $\theta$ was measured at different distance intervals from the trunk (from 2 to $30 \mathrm{~m}$ ) and at different depths, at intervals of $20 \mathrm{~cm}$ for the first metre and every $50 \mathrm{~cm}$ until a maximum depth of $250 \mathrm{~cm}$ (occasionally $300 \mathrm{~cm}$ ). In some cases, the maximum investigated depth was only $100 \mathrm{~cm}$ because of the presence of coarse gravel. Details of distances, depth and period measurements at each site are given in Table II. Measurements from 0 to $100 \mathrm{~cm}$ depth started in May 2002 for $C L, S T$, and $D B$ sites, and in January 2003 for $B A$. Measurements below $100 \mathrm{~cm}$ depth started in June 2003 for $C L$, and in February 2004 for $B A$. Measurements were made monthly within the first week of each month, until December 2005.

Soil water content was measured by Time Domain Reflectometry (TDR) (Tektronic model 1502 C). TDR-probes were constructed manually according to Vicente et al. [45]. Each probe comprised two parallel rods made of stainless steel, $20 \mathrm{~cm}$ in length and sharpened at the tip to facilitate their introduction into the soil. Rod diameter was $0.6 \mathrm{~cm}$ and the separation between their axes was $3 \mathrm{~cm}$. One rod was connected to a conductor of a low ohm-resistance coaxial cable and the other was connected to the mesh of the cable. All connections were coated with an epoxy resin (Stuers kit EPOFIX ${ }^{\circledR}$ ) which acted as an electrical insulator, and held the rods firmly in a parallel position. TDR-probes were placed vertically in the undisturbed soil. During installation, efforts were made to ensure maximum contact between the rods and the soil. Soil was drilled with a stainless steel soil column cylinder with a cutting shoe and a removable cover $(10 \mathrm{~cm}$ diameter, $1 \mathrm{~m}$ length; Eijkelkamp) and was inserted into the soil with a heavy electrical powered percussion hammer (Makita HM 1800). A total of 796 TDR-probes were installed on undisturbed soil. The calibration curve of the TDR-probes was done in the laboratory with soil collected from the entire profiles of the experimental sites [4]. Calibration curve yield mass- or volume-based water content because soil bulk density was measured together with TDR measurements and $\theta$.

Before refilling soil bores, with the extracted soil, where TDRprobes were installed, soil column cylinders were used to determine the soil bulk density. Soil columns were cut and weighted every $20 \mathrm{~cm}$, and aliquots were taken for the determination of $\theta$, in order to get the dry weight of soil. A total of 1290 determinations were done. Aliquots of three randomly selected trees per plot were used for the determination of the soil physical characteristics (in fine earth fraction, particle $<2 \mathrm{~mm}$ diameter). Soil organic matter was determined by the Walkley and Black method, using samples for all distances, but grouping them every $40 \mathrm{~cm}$, below $1 \mathrm{~m}$ depth. A total of 237 determinations were made. Texture (sand, silt and clay contents) and retention properties were determined only for the two extreme distances ( 2 and 20-30 m) every $20 \mathrm{~cm}$ depth, with a total of $206 \mathrm{de}-$ terminations for each parameter. Texture was determined by the pipet 
Table I. The main characteristics of the soils and $Q$. ilex trees at the experimental sites (mean values).

\begin{tabular}{|c|c|c|c|c|c|c|c|c|}
\hline \multirow[t]{2}{*}{ Site } & \multirow[t]{2}{*}{ Soil type } & \multirow[t]{2}{*}{ Depth $(\mathrm{cm})$} & \multirow[t]{2}{*}{ Sand $(\%)$} & \multirow[t]{2}{*}{ Silt (\%) } & \multirow[t]{2}{*}{ Clay $(\%)$} & \multirow[t]{2}{*}{$\mathrm{BD}^{2}\left(\mathrm{~g} \mathrm{~cm}^{-3}\right)$} & \multicolumn{2}{|c|}{ Water $\left(\mathrm{cm}^{3} \cdot \mathrm{cm}^{-3}\right)$} \\
\hline & & & & & & & $\mathrm{FC}^{3}$ & $\mathrm{WP}^{4}$ \\
\hline Cerro Lobato $(C L)$ & & $0-20$ & 55.9 & 23.0 & 21.1 & 1.49 & 23.9 & 10.9 \\
\hline Slope: $4 \%$ & Chromic & $20-40$ & 37.2 & 26.1 & 36.7 & 1.65 & 29.9 & 16.1 \\
\hline $\mathrm{Cw}^{1}: 9.9 \mathrm{~m}$ & Luvisol & $40-60$ & 33.2 & 27.9 & 38.9 & 1.43 & 30.5 & 17.6 \\
\hline \multirow[t]{2}{*}{16 trees ha $^{-1}$} & & $60-80$ & 44.5 & 19.3 & 36.1 & 1.46 & 31.4 & 16.3 \\
\hline & & $80-100$ & 46.6 & 16.5 & 37.0 & 1.53 & 34.8 & 17.8 \\
\hline El Baldío $(B A)$ & & $0-20$ & 58.3 & 15.5 & 26.2 & 1.49 & 29.1 & 13.2 \\
\hline Slope: $0 \%$ & Chromic & $20-50$ & 39.7 & 18.3 & 42.0 & 1.65 & 36.8 & 19.8 \\
\hline $\mathrm{Cw}: 12.4 \mathrm{~m}$ & Luvisol & $50-80$ & 38.5 & 18.5 & 43.0 & 1.45 & 36.5 & 19.8 \\
\hline 18 trees ha $^{-1}$ & & $80-120$ & 48.3 & 14.5 & 37.2 & 1.50 & 34.4 & 17.3 \\
\hline Sotillo $(S T)$ & & $0-20$ & 51.8 & 30.3 & 17.9 & 1.49 & 20.3 & 9.7 \\
\hline Slope: $2 \%$ & Chromic & $20-40$ & 39.7 & 23.1 & 37.2 & 1.65 & 34.8 & 18.9 \\
\hline $\mathrm{Cw}: 10.9 \mathrm{~m}$ & Luvisol & $40-60$ & 38.8 & 23.0 & 38.2 & 1.43 & 33.7 & 118.4 \\
\hline \multirow[t]{2}{*}{14 trees $\mathrm{ha}^{-1}$} & & $60-80$ & 44.6 & 21.7 & 33.8 & 1.46 & 30.3 & 15.9 \\
\hline & & $80-100$ & 48.6 & 5.8 & 45.6 & 1.53 & 39.1 & 19.6 \\
\hline Dehesa Boyal $(D B)$ & & $0-23$ & 34.4 & 46.4 & 19.2 & 1.45 & 16.7 & 10.4 \\
\hline Slope: $2 \%$ & Eutric & $23-35$ & 29.6 & 49.5 & 20.9 & 1.55 & 18.4 & 12.3 \\
\hline Cw: 9.9 m & Leptosol & $35-60$ & 32.0 & 55.6 & 12.4 & 1.60 & 12.8 & 9.1 \\
\hline 10 tree ha $^{-1}$ & & & & & & & & \\
\hline
\end{tabular}

${ }^{1} \mathrm{Cw}$ : Canopy width.

${ }^{2}$ BD: Soil bulk density.

${ }^{3} \mathrm{FC}$ : Water content at field capacity $(\mathrm{pF} 2.5)$.

${ }^{4} \mathrm{WP}$ : Water content at wilting point $(\mathrm{pF} 4.2)$.

method. Soil water content at field capacity (FC), and at wilting point (WP) were determined in a Richards' chamber. Available soil water capacity $(\mathrm{AW})$ was determined by the difference between water content at field capacity $(\mathrm{pF} 2.5$ ) and water content at wilting point ( $\mathrm{pF} 4.2$ ), taking into account the percentage of gravels.

Finally, predawn and midday water potentials were measured in Q. ilex trees during the summer of 2002 and 2003 by means of the Scholander pressure chamber. In 2002, measurements were conducted at the $C L$ and $S T$ sites on 6 trees per site using 4 sun exposed current-year shoots per tree, during 6 days from the end of May to the mid September. In 2003, measurements were conducted on 16 trees at the $B A$ site, using 3 current-year shoots per tree, during 8 days from the end of February to mid October.

\subsection{Data analysis}

Four farms (sites) represented 4 replicates, but data were not pooled together because they did not follow the same protocol of measurement regarding to distance, depth and period. Comparison of mean values of $\theta$ were conducted by means of three-ways ANCOVAs, with distance, depth, and season as independent variables, $\theta$ as dependent variable and trees canopy width as the covariate. A single ANCOVA was applied per site, except for $B A$, where two ANCOVAs were applied, first with data of $0-100 \mathrm{~cm}$ depth and 5 distances, and second with data of the whole profile $(0-250 \mathrm{~cm})$ grouped every $50 \mathrm{~cm}$ and two extreme distances. In all cases, monthly data were grouped in four natural seasons, winter, spring, summer and autumn, coinciding with the wet, drying, dry and recharge periods, respectively. Comparisons of mean values of the soil physical parameters were conducted by means of two-ways ANCOVAs with distance and depth as independent variables and tree density as the covariate. Predawn leaf water potentials were compared each year by means of one way ANOVAs, with month as independent variable and water potential as dependent variable. The same analysis was applied per midday leaf water potentials data. For statistical analysis the program STATISTICA v.5 was used.

\section{RESULTS}

\subsection{Soil physical properties}

Most of the parameters analysed were different in soils located beneath as compared to those beyond the tree canopy (Fig. 1). In terms of soil texture, the sand and silt content was similar in both zones $(p=0.25$ and 0.07 , respectively; d.f. $=$ $1-176)$ whilst clay content was significantly higher beneath than beyond the tree canopy $\left(p=7.7 \times 10^{-5}\right.$; d.f. $\left.=1-176\right)$. A significant interaction clay content $\times$ depth was detected $(p=0.022$; d.f. $=14-176)$, indicating that clay content differences between zones were only significant from 1 to $2 \mathrm{~m}$ depth (Fig. 1). Soil organic matter was significantly higher beneath than beyond the tree canopy ( $p=0.002$; d.f. $=4-202)$, with a significant interaction with depth $(p=0.019$; d.f. $=24-202)$, 
Table II. Results after comparison of soil water content values in four dehesa sites. A three-way ANOVA was applied for each site, with distance, depth and season as independent variables, soil water content as dependent variable, and trees canopy width as the covariate.

\begin{tabular}{|c|c|c|c|c|c|}
\hline \multirow[b]{2}{*}{ Factors } & \multicolumn{5}{|c|}{ Sites } \\
\hline & $\mathrm{CL}^{1}$ & $\mathrm{BA} \mathrm{I}^{2}$ & $\mathrm{BA} \mathrm{II}^{3}$ & $\mathrm{ST}^{4}$ & $\mathrm{DB}^{4}$ \\
\hline Distance & $\begin{array}{c}\mathrm{F}_{3,5693}=124 \\
p<0.001 \\
2=5<10<20\end{array}$ & $\begin{array}{c}\mathrm{F}_{4,11305}=29.4 \\
p<0.001 \\
5<2,10,30<20\end{array}$ & $\begin{array}{c}\mathrm{F}_{1,5730}=10.5 \\
p=0.001 \\
2<30\end{array}$ & $\begin{array}{c}\mathrm{F}_{3,1421}=10.0 \\
p<0.001 \\
2=5<10<20\end{array}$ & $\begin{array}{c}\mathrm{F}_{3,577}=5.8 \\
p<0.001 \\
2=5=10<20\end{array}$ \\
\hline$\overline{\text { Depth }}$ & $\begin{array}{c}\mathrm{F}_{2,5693}=1074 \\
p<0.001 \\
25<75<150\end{array}$ & $\begin{array}{c}\mathrm{F}_{3,11305}=2514 \\
p<0.001 \\
10<30<50<80\end{array}$ & $\begin{array}{c}\mathrm{F}_{3,5730}=1420 \\
p<0.001 \\
25<75<250<150\end{array}$ & $\begin{array}{c}\mathrm{F}_{3,1421}=110 \\
p<0.001 \\
10<30<50<80\end{array}$ & $\begin{array}{c}\mathrm{F}_{3,577}=14.1 \\
p<0.001 \\
10<30=50<80\end{array}$ \\
\hline \multirow[t]{2}{*}{ Season $^{5}$} & $\begin{array}{c}\mathrm{F}_{3,5693}=251 \\
p<0.001\end{array}$ & $\begin{array}{c}\mathrm{F}_{3,11305}=1275 \\
p<0.001\end{array}$ & $\begin{array}{c}\mathrm{F}_{3,5730}=111 \\
p<0.001\end{array}$ & $\begin{array}{c}\mathrm{F}_{3,1421}=108 \\
p<0.001\end{array}$ & $\begin{array}{c}\mathrm{F}_{3,1421}=244 \\
p<0.001\end{array}$ \\
\hline & & & $\mathrm{Su}<\mathrm{S} p<\mathrm{A}<\mathrm{W}$ & & \\
\hline $\begin{array}{l}\text { Canopy } \\
\text { width }\end{array}$ & $\begin{array}{c}\mathrm{F}_{1,5693}=25.4 \\
p<0.001\end{array}$ & $\begin{array}{c}\mathrm{F}_{1,11305}=321 \\
p<0.001\end{array}$ & $\begin{array}{c}\mathrm{F}_{1,5730}=54.7 \\
p<0.001\end{array}$ & $\begin{array}{c}\mathrm{F}_{1,1421}=65.1 \\
p<0.001\end{array}$ & $\begin{array}{c}\mathrm{F}_{1,577}=6.3 \\
p=0.012\end{array}$ \\
\hline $\begin{array}{l}\text { Distance } \\
\times \text { depth }\end{array}$ & $\begin{array}{c}\mathrm{F}_{6,5693}=31.5 \\
p<0.001\end{array}$ & $\begin{array}{c}\mathrm{F}_{12,11305}=6.5 \\
p<0.001\end{array}$ & $\begin{array}{c}\mathrm{F}_{3,5730}=31.6 \\
p<0.001\end{array}$ & $\begin{array}{c}\mathrm{F}_{9,1421}=5.7 \\
p<0.001\end{array}$ & $\begin{array}{c}\mathrm{F}_{9,577}=1.4 \\
p=0.207\end{array}$ \\
\hline $\begin{array}{l}\text { Distance } \\
\times \text { season }\end{array}$ & $\begin{array}{c}\mathrm{F}_{6,5693}=2.9 \\
p=0.002\end{array}$ & $\begin{array}{c}\mathrm{F}_{12,11305}=1.3 \\
p=0.185\end{array}$ & $\begin{array}{c}\mathrm{F}_{3,5730}=2.2 \\
p=0.09\end{array}$ & $\begin{array}{c}\mathrm{F}_{9,1421}=0.95 \\
p=0.484\end{array}$ & $\begin{array}{c}\mathrm{F}_{9,577}=2.0 \\
p=0.033\end{array}$ \\
\hline $\begin{array}{l}\text { Depth } \\
\times \text { season }\end{array}$ & $\begin{array}{c}\mathrm{F}_{6,5693}=1.6 \\
p<0.157\end{array}$ & $\begin{array}{c}\mathrm{F}_{9,11305}=19.2 \\
p<0.001\end{array}$ & $\begin{array}{c}\mathrm{F}_{9,5730}=5.6 \\
p<0.001\end{array}$ & $\begin{array}{c}\mathrm{F}_{9,1421}=4.0 \\
p<0.001\end{array}$ & $\begin{array}{c}\mathrm{F}_{9,577}=3.9 \\
p<0.001\end{array}$ \\
\hline
\end{tabular}

${ }^{1}$ Distance $(2,5,10$ and $20 \mathrm{~m})$; depth $(0-50 ; 50-100 ;>100 \mathrm{~cm})$. Measurements from May 2002 to December 2005.

${ }^{2}$ Distance $(2,5,10,20$ and $30 \mathrm{~m})$; depth $(0-20 ; 20-40 ; 40-60 ; 70-90 \mathrm{~cm})$. Measurements from January 2003 to December 2005.

${ }^{3}$ Distance (2 and $\left.30 \mathrm{~m}\right)$; depth $(0-50 ; 50-100 ; 100-200 ; 200-250 \mathrm{~cm})$.

${ }^{4}$ Distance $(2,5,10$ and $20 \mathrm{~m})$; depth $(0-20 ; 20-40 ; 40-60 ; 70-90 \mathrm{~cm})$. Measurements from May 2002 to January 2003.

${ }^{5}$ Seasons: winter (W); spring (Sp); summer (Su); autumn (A).

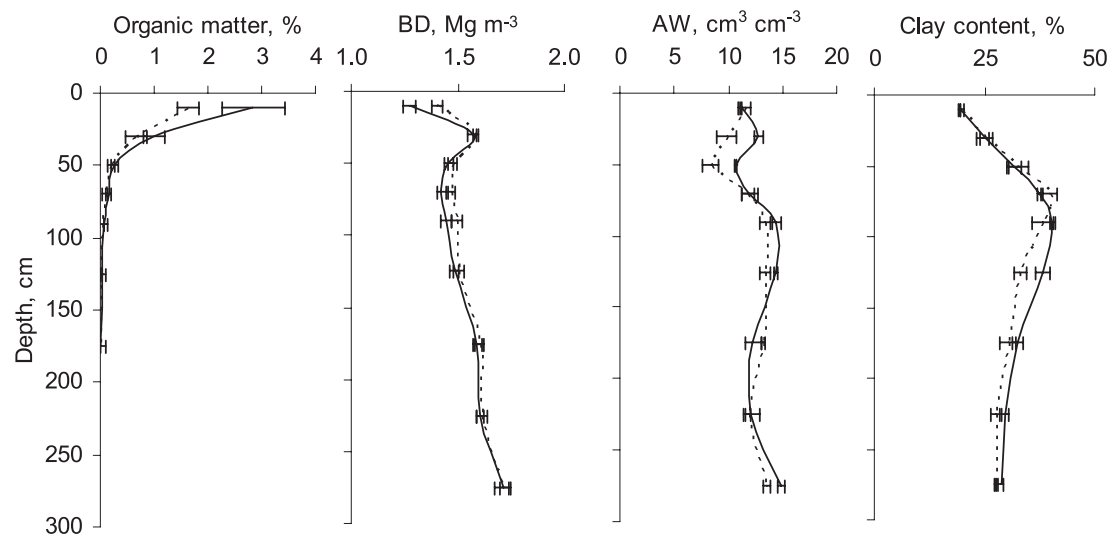

Figure 1. Mean values of several soil physical parameters measured beneath (solid lines) and beyond (dashed lines) the tree canopy (2, and 20-30 m from the tree trunk, respectively), at different depths. Parameters refer to soil organic matter, soil bulk density (BD), available soil water capacity (AW, defined as the difference between field capacity and permanent wilting point), and clay content. Data have been pooled from all the study sites and from all the trees within the sites. Horizontal bars indicate standard errors.

indicating that differences were only significant within the two first layers $(0-20$, and $20-40 \mathrm{~cm})$. According to the clay and the organic matter spatial variability, the soil beneath the tree canopy showed significantly higher values of FC, WP and AW, than soil located beyond the tree canopy ( $p<0.001$ for each of the three parameters, d.f. $=1-176)$. Similarly, soil bulk density showed values significantly lower beneath than beyond tree canopy (1.50 and $1.54 \mathrm{~g} \mathrm{~cm}^{-3}$, respectively; $p=0.004$; d.f. $=1-1215)$, with no significant interactions with depth $(p=$ $0.18 ;$ d.f. $=56-1215)$.

\subsection{Time course of average soil water content}

Seasonal trends of soil water content averaged across the upper first and second meter of the soil profile are presented in Figure 2, for the two experimental sites in which the TDR-probes were installed at deeper depths. $S T$ and $D B$ showed similar trends within the first meter depth (data not shown). The expected cycle of wet and dry periods occurred for all the distances analysed, with a very rapid recharge during the autumn and a less rapid drying during the spring. 

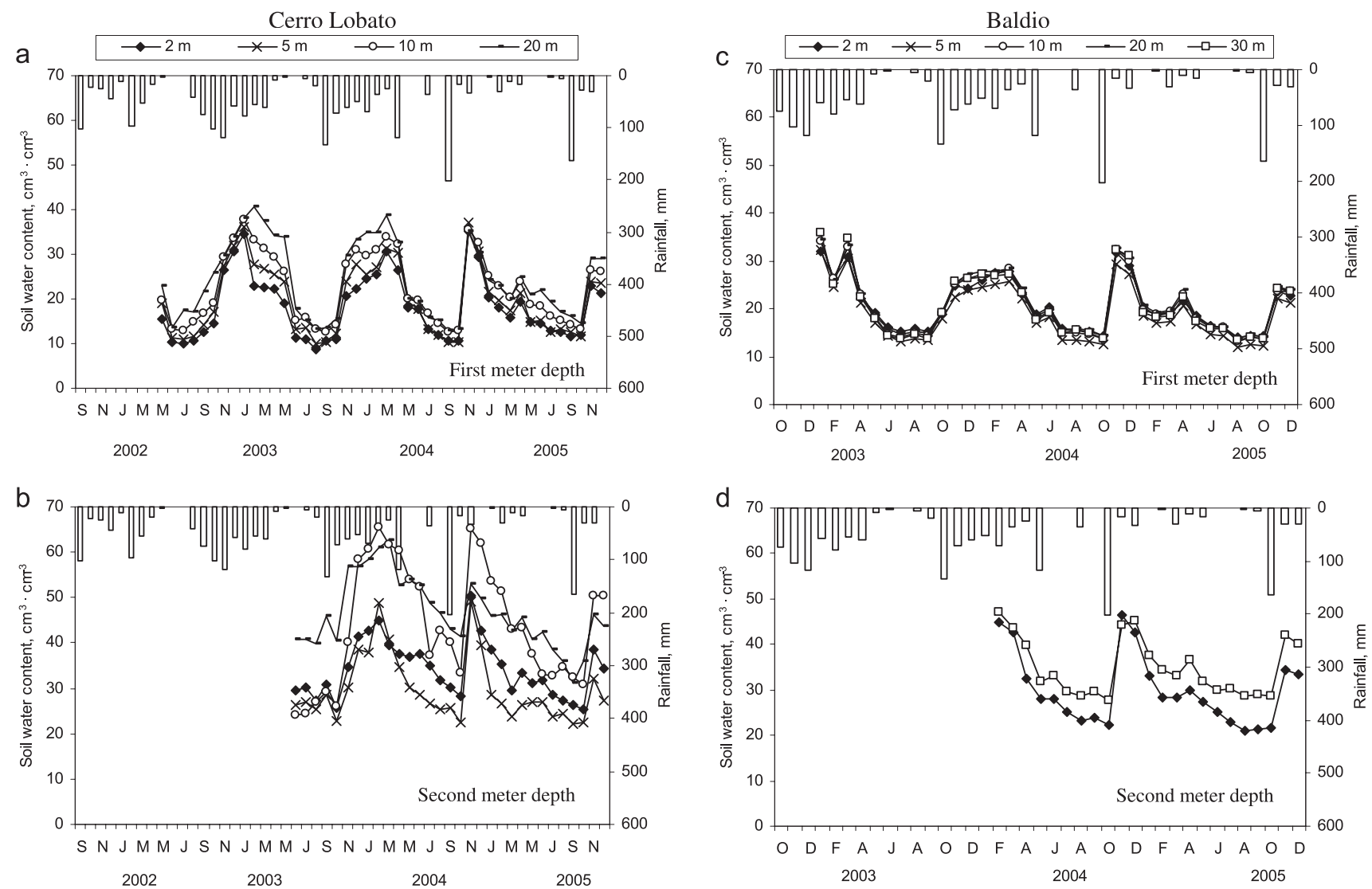

Figure 2. Seasonal evolution of average soil water content at different distances from the tree trunk in the first and second meter depth at Cerro Lobato ( $\mathbf{a}$ and $\mathbf{b}$, respectively), and at Baldío (c and $\mathbf{d}$, respectively). Bars indicate monthly precipitation.

Autumn rainfalls refilled quickly the soil water storage, with maximum values in January of 2003, March of 2004, and November of 2004. Soil water content typically remained more or less constant until the end of winter if the rainfall was abundant during this season. In contrast, during unusually dry winters such as that encountered during 2005, the soil water content decreased quickly due to the scarcity of winter rainfall (i.e. $51 \mathrm{~mm}$ between November and February of 2005 in comparison to 358 and $254 \mathrm{~mm}$ of 2003 and 2004, respectively). Furthermore, low spring rainfall decreased soil water content quickly until June or July. Soil water content remained nearly constant during the rest of the summer. Each year, minimum and maximum soil water content values during the dry and wet periods were similar at the different distances and depth of measurement, despite strong variation in overall precipitation $(418,583,604$, and $318 \mathrm{~mm}$ during the hydrological years 2001-2002, 2002-2003, 2003-2004 and 2004-2005, respectively).

As a general trend for all the experimental sites, during the dry and wet periods soil water content was lower beneath than beyond the tree trunk (Figs. 2a, 2c), with significant differences in most sites (Tab. II). Minimum and maximum soil water content contents within the first and second meter depths were found to be at 2 or $5 \mathrm{~m}$, and at 20 or $30 \mathrm{~m}$ from the tree trunk, respectively. Canopy width affected significantly this trend in all sites (Tab. II), with higher differences among distances in the biggest trees.

Average soil water content was higher in the second than in the first meter depth $(p<0.0001)$ during both dry and wet periods at every distance studied. Significant interactions between distances and depths were found in most sites, generally due to higher differences between distances among 50-200 cm depth, and increased differences between depths beyond the tree trunk (Tab. II). A significant interaction depth $\times$ season was found because differences among seasons were higher between 50 and $150 \mathrm{~cm}$ depth than at other depths, and because higher differences in soil water content values between depths occurred in winter and summer.

\subsection{Time change in the soil water content profiles}

Soil recharge beneath and beyond the tree canopy was complete for most of the profile, with soil water content values close or even higher to FC (Fig. 3). Only at the deepest layers, near $3 \mathrm{~m}$ depth, did soil recharge seem incomplete. At $2 \mathrm{~m}$ from the tree trunk, soil water content values close to the WP were observed at the end of the dry season (Fig. 3a). However, at $30 \mathrm{~m}$ of distance, an important amount of available water remained unused by vegetation in the deeper layers of the soil 


\begin{tabular}{|c|c|c|c|c|}
\hline 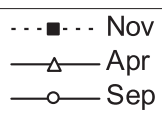 & $\begin{array}{c}\cdots \text {. . Dec } \\
\longrightarrow \text { May } \\
-* \text { - Oct }\end{array}$ & $\begin{array}{l}\cdots \bullet \cdots \text { Jan } \\
-+- \text { Jun } \\
\text { FC }\end{array}$ & $\begin{array}{l}\ldots \ldots \text { Feb } \\
\ldots \text { J Jul } \\
\text { WP }\end{array}$ & $\begin{array}{l}\cdots * \cdots \text { Mar } \\
\longrightarrow \text { Aug }\end{array}$ \\
\hline
\end{tabular}

a Soil water content, $\mathrm{cm}^{3} \cdot \mathrm{cm}^{-3}$

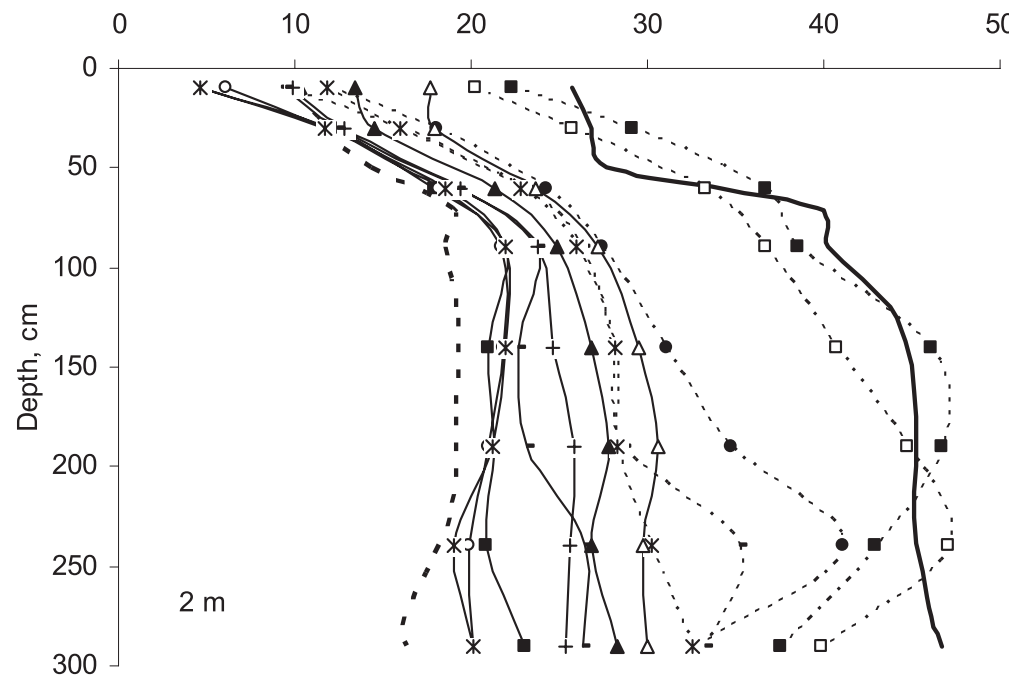

b Soil water content, $\mathrm{cm}^{3} \cdot \mathrm{cm}^{-3}$

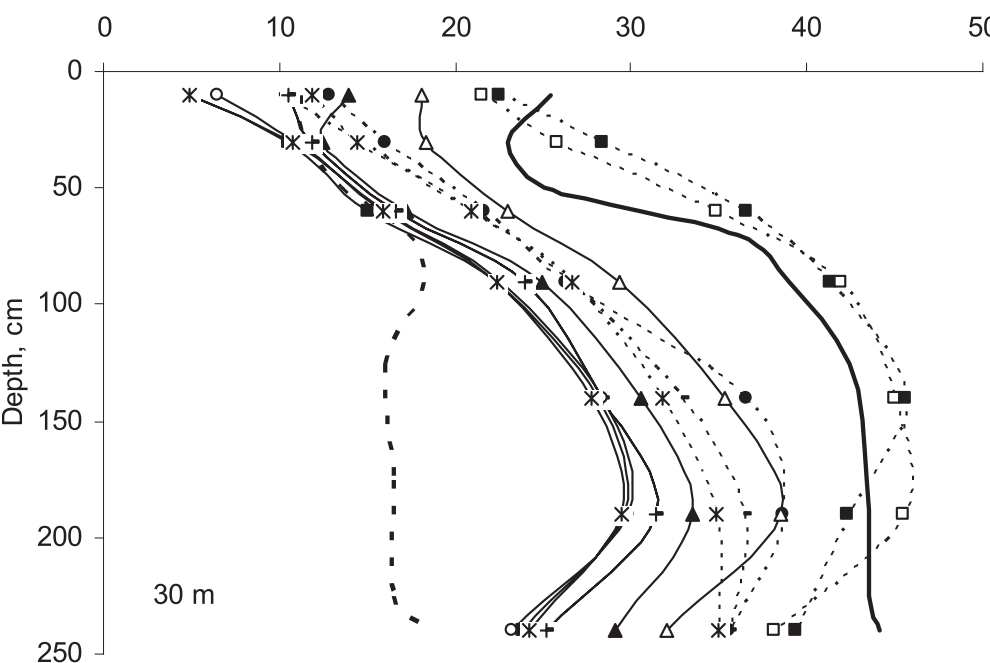

Figure 3. Soil water content profiles at $2 \mathrm{~m}$ (a) and at $30 \mathrm{~m}$ from the tree trunk (b) at Baldío, from November 2004 to October 2005 . Solid and dashed lines indicate water content at field capacity (FC) and at wilting point (WP), respectively.

(Fig. 3b). A similar temporal trend in the soil water content profile was observed for the rest of the sites and years. It is important to note that at the end of the dry season, soil water content below $100 \mathrm{~cm}$ depth has been extracted more intensively beneath the tree canopy than beyond it (Fig. 4). In wet season, soil water content values from the upper $100 \mathrm{~cm}$ were similar beneath and beyond the tree trunk, whilst between 100 and $200 \mathrm{~cm}$ depth, they were higher beyond than beneath the tree trunk. Nevertheless, in $C L$ the observed increase in soil water content during wet season was higher beneath than beyond the tree trunk (Fig. $4 \mathrm{a}$ ).
In 2003 and 2004 the soil dried out from February or March until the beginning of June (Fig. 2). In 2005, however, the soil dried out since November of the previous year and in January the reserve of water in the first meter depth was practically depleted (Fig. 3). From January to February 2005, a higher amount of water was extracted from 150 to $250 \mathrm{~cm}$ depth than from other depths. Soil continued drying out from 200 to $250 \mathrm{~cm}$ depth during February at $2 \mathrm{~m}$ from the tree trunk. At the end of March a new soil moistening was observed for the first $200 \mathrm{~cm}$ of soil. The depletion of water of the upper $250 \mathrm{~cm}$ of soil varied little from April onwards, i.e. soil water 


\begin{tabular}{ll}
$\ldots \ldots$ Dry, $2 \mathrm{~m}$ & $\cdots \times$ Dry, $30 \mathrm{~m}$ \\
$\longrightarrow$ Wet, $2 \mathrm{~m}$ & $\times$ Wet, $30 \mathrm{~m}$ \\
\hline
\end{tabular}

a

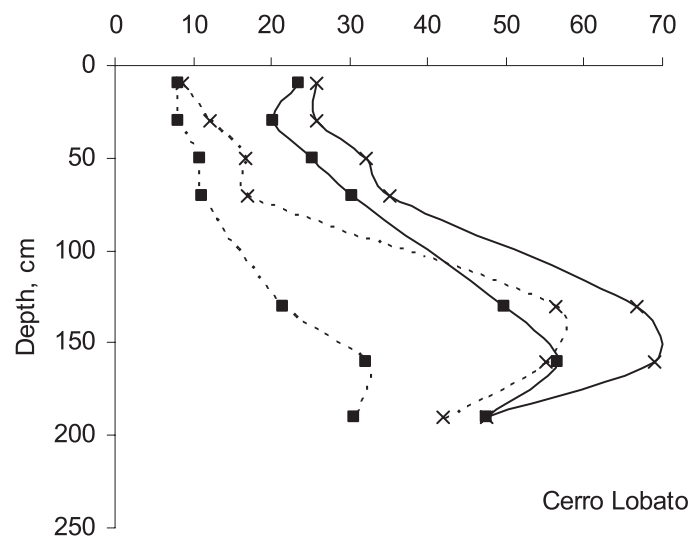

Soil water content, $\mathrm{cm}^{3} \cdot \mathrm{cm}^{-3}$

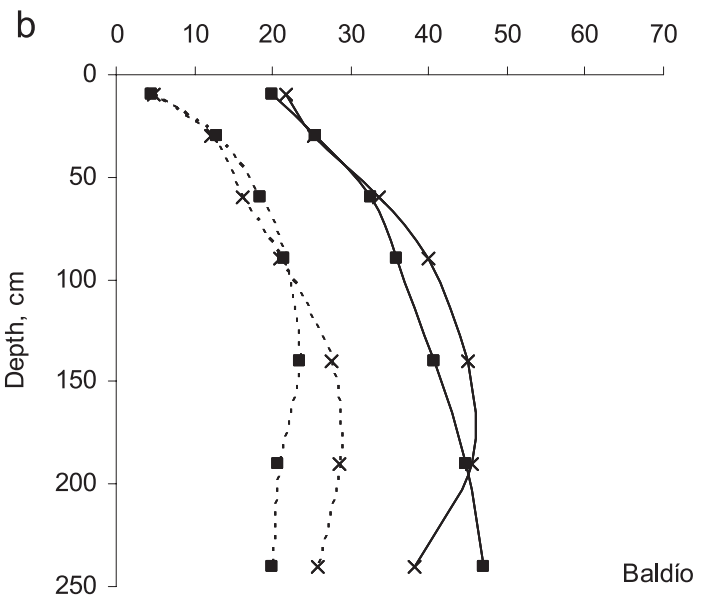

Figure 4. Soil water content profiles at 2 and $30 \mathrm{~m}$ from the tree trunk during two extreme soil water content months, the driest (October, Dry) and the wettest (December, Wet) of 2004 at Cerro Lobato (a) and at Baldío (b).

content profiles remained almost constant with a very low water extraction by vegetation.

\subsection{Time course of leaf water potential}

Predawn leaf water potentials along the two consecutive summers were relatively high (Fig. 5). Although a significant decrease was observed from spring to summer, values remained always above $-1 \mathrm{MPa}$. A significant increase of predawn water potential values was observed from mid summer (when PET and night transpiration start to decrease) to the end of the summer ( $p \leq 0.05)$, even without rainfall, during both summers. A similar pattern was found for midday leaf water potential with values always above $-2.5 \mathrm{MPa}$ (Fig. 5).

\section{DISCUSSION}

\subsection{Effect of trees on soil water content distribution}

Soil under the tree cover showed significantly higher waterholding capacity relative to soil located in the adjacent areas. Similar results were reported by Joffre and Rambal [19] in southern sub-humid dehesas, which were interpreted as a positive effect of the tree. The improved water holding capacity beneath the canopy could be explained by the observed increase in soil organic matter and clay content, and the improvement of the soil structure (decrease of bulk density) in relation to adjacent areas. Such a positive effect of trees on soil physical properties has also been described for other agroforestry systems $[27,48]$. Furthermore, in support of the present study, an increase of fine particles beneath dehesa trees has been described before [19]. To our knowledge, soil texture modification by trees has not been reported before, but it would be difficult to consider this as an effect of the trees given that soil texture is a basic property of the soils, not readily subjected to change in the field [1]. The longevity $Q$. ilex trees, up to several hundred years, could help to justify this result, but the hypothesis that trees or seedlings survive in already preexisting favorable sites should also be considered. In this case, the better physical condition of soil beneath the tree canopy would not be a consequence of the presence of the trees but the cause of tree distribution in dehesas, as Geiger et al. [13] have described for some Sahelian savanna-trees.

Irrespective of the origin of the improved water-holding capacity in the sub-canopy areas, soil water content decreased in the vicinity of the tree relative to the adjacent areas, in a similar way to that described for many other agroforestry systems [23, 48]. This phenomenon is explained as a consequence of a decrease water input, and an increase of water output in the sub-canopy area. The evergreen $Q$. ilex presents a rainfall interception of about $30 \%$ [26] and absorbs water from the soil continuously throughout the year with moderately high transpiration rates in winter and summer $[5,17]$. In our study, water interception and transpiration should overweigh the positive effects of trees on water-holding capacity, as observed in North American savannas [27]. A similar pattern has been reported by Nunes et al. [30], for Portuguese dehesas with an annual rainfall of $666 \mathrm{~mm}$. In more humid dehesas (annual rainfall above $700 \mathrm{~mm}$ ) soil water content was always higher beneath than beyond the tree canopy [20]. Therefore, the widely accepted idea that trees increase soil water content in dehesas would not be applicable in dry sites, where canopy water interception and water absorption by the tree root system are likely to influence the spatial and temporal changes in soil water content. These results indicate the importance of the edapho-climatic conditions in the interpretation of tree-pasture interactions.

\subsection{Lateral water uptake by trees}

Thinning usually implies a higher water availability for remnant trees because a lower water interception and 


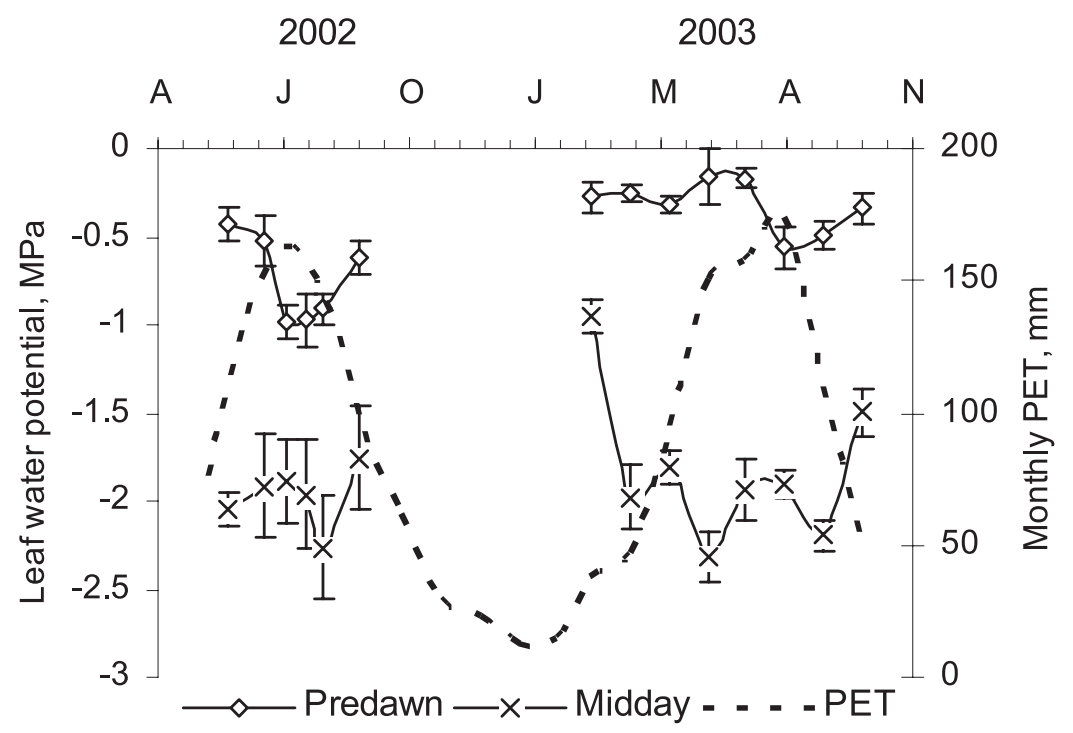

Figure 5. Leaf water potential values obtained during the summer of 2002 ( $C L$ and $S T$ sites) and 2003 (BA site) in isolated Quercus ilex trees, and monthly potential evapotranspiration values (PET). Predawn and midday water potential were measured in current year shoots. Vertical bars indicate standard errors.

transpiration, resulting in a diminution of length and intensity of water stress [46]. This is especially relevant in dehesas, where the survival of trees facing severe drought conditions is only possible if the tree root system extends beyond the influence of the tree canopy [20]. Soil water beyond the tree canopy should be considered to explain the transpiration rate of $Q$. ilex in dehesas [20]. Herbaceous plants in dehesas are mostly annuals [24] which usually dry during May. However, soil water content continues decreasing after May, both beneath and beyond the tree trunk, and at $200-300 \mathrm{~cm}$ depth. This indicated that $Q$. ilex trees were consuming this water.

Tree root density of $Q$. ilex trees decreases slightly with the distance from the tree trunk, spreading mostly within the intertrees space, around $33 \mathrm{~m}$ of distance [29]. Tree roots access water through a large volume of soil thus taking advantage of the low tree density characteristic of dehesas. Larger lateral root spread was found in plants and trees growing at low densities in dry environments $[10,41]$. In this way, natural savannas were defined as the biotic response to alternating wet and dry seasons, the amount of soil water content available controlling the densities of woodland and grass [9].

In our study, soil water depletion was higher beneath than beyond the tree trunks, reaching the wilting point beneath but not beyond, giving support to previous work defining the tree root density pattern [29]. The higher tree root density beneath the tree trunk compared to that beyond it, allows trees to absorb a higher proportion of water. Passioura [31] stressed the need for a dense root system in order to adequately exploit water in unsaturated soils, since the difficulty of water movement in the soil is greater than the force with which it is retained. Indeed, root water uptake models often use a root length densitydependent sink term profile (e.g., $[6,47])$, although sensitivity analysis have often shown that soil water content dynamic is more sensitive to soil hydraulic properties than to root den- sity, at least under certain circumstances, e.g., medium-fine textured soil [15], non-water limited soils [44], etc. Nevertheless, the role of roots seems to be particularly important when soil moisture limits evapotranspiration $[11,44]$, as in the cases of the dehesas here studied.

Anyway, the incomplete depletion of soil water found at 20-30 $\mathrm{m}$ of distance indicates that the tree density in dehesas could be below the optimum relative to soil water availability. Nevertheless, dehesa tree density may be controlled by episodes of severe drought and may maintain a sub-optimum tree density to allow long term tree survival - even more important in the present context of the climate change [22]. In the sites studied there was neither tree mortality nor premature leaf dry. Moreover, with a sub-optimal tree density, the treegrass system of dehesas is not able to use the entire rainfall amount. Any increase in tree density would cause a decrease in the already low water yield of semiarid dehesas [20], where water yield is an important ecosystem service for human.

\subsection{Deep water consumption by trees}

As the drought period progressed, an increasing proportion of water was extracted from deeper soil horizons, confirming previous studies $[12,35]$. In $Q$. ilex trees growing at the same sites, transpiration and photosynthetic rates were high [28] in comparison to common values reported for $Q$. ilex in closed forest [38]. These results indicate that trees were consuming a high volume of water and grew in well-watered conditions even during the two consecutive dry summers.

In different farm wells located within the study area we have observed that groundwater throughout the summer was at about 5-10 m depth, from which trees could be tapping deep water, similarly to the dehesas studied by Davis et al. [5]. 
These authors also reported high water potential values for $Q$. ilex during summer in Central Portugal. $Q$. ilex roots were found to reach at least $5 \mathrm{~m}$ depth in our study area [29]. Rambal [35] detected water consumption up to a depth of $5 \mathrm{~m}$ by $Q$. coccifera in Southern France whilst for Californian oaks, roots deeper than $8.5 \mathrm{~m}$ were reported [3]. In fact, deep roots (taproots) could be a hundred times more efficient in absorbing water than roots in drier soils [37].

Nevertheless, assuming that any variation in $\theta$ during summer drought was due to tree transpiration - pasture understory is completely dry and evaporation is negligible because soil surface is very dry -, this variation, although small, can also explain the favourable water status of the trees studied. For instance, integrating $\theta$ variation in $B A$ site in the first $3 \mathrm{~m}$ depth and at $13.3 \mathrm{~m}$ of distance - the half of mean distance among trees with 18 trees $\mathrm{ha}^{-1}$-, the transpiration rate estimated for the summer period was $7265 \mathrm{~L} \mathrm{ha}^{-1}$ day $^{-1}$ (averaging July, August and September, 2004 and 2005). This transpiration rate means $16.7 \%$ of potential evapotranspiration estimated on a surface basis. On a tree basis, tree transpiration reached up to $404 \mathrm{~L} \mathrm{tree}^{-1} \mathrm{~d}^{-1}$ or $3.34 \mathrm{~L} \mathrm{~m}^{-2}$ canopy d $\mathrm{d}^{-1}$, values much higher than those reported for more dense dehesas (40 trees ha ${ }^{-1}$ with $34 \%$ canopy cover versus 18 trees ha ${ }^{-1}$ and $21 \%$ in $B A$ site) $[16,17]$. Hence, although $\theta$ varied little during summer, the huge volume of soil explored by $Q$. ilex root system [29], allows trees to uptake a high volume of water, 19.3, 43.3 and $37.4 \%$ from the first, second and third meter depth, respectively.

\subsection{Tree-herbaceous competition for soil water}

We have observed a certain degree of spatial separation in relation of soil water between herbaceous plants and trees. Soil dried uniformly only for the uppermost $50 \mathrm{~cm}$ of the soil, while at deeper layers soil water content increased with the distance from the tree trunk, indicating that herbaceous plants did not use water below $50 \mathrm{~cm}$ depth. Herbaceous roots are located mostly in the upper $30 \mathrm{~cm}$ of soil [29]. Annual and perennial grasses absorb water from the uppermost 40 and $60 \mathrm{~cm}$ of the soil, respectively [21]. By contrast, $Q$. ilex trees have a higher dependence upon the deep water because of their low root density in the uppermost soil layers, in comparison to herbaceous plants [29]. Thus, whilst water limitation is an important feature in most dehesas, it seems that trees and grasses are, for the most part, consuming water from different soil layers, thus preventing below-ground competition.

Acknowledgements: We thank María Jesús Montero, José Jesús Obrador, and Eustolia García for their valuable collaboration in field work. This study was supported by The European Union (SAFE project, QLX-2001-0560), The Spanish Ministerio de Ciencia y Tecnología (MICASA project, AGL-2001-0850) and the Consejería de Educación (Junta de Extremadura) (CASA project, 2PR02C012). Elena Cubera was awarded a grant by Consejería de Educación, Ciencia y Tecnología (Junta de Extremadura) and Fondo Social Europeo.

\section{REFERENCES}

[1] Brady N.C., Weil R.R., Elements of the Nature and Properties of Soils, 2nd Ed. Prentice Hall, Upper Saddle River, New Jersey, 2004.

[2] Canadell J., Zedler P.H., Woody-plant underground structures, in: Kalin Arroyo M., Zedler P.H, Fox M.D. (Eds.), Ecology and Biogeography of Mediterranean Ecosystems in Chile, California and Australia, Springer-Verlag, New York, 1995, pp. 177-210.

[3] Canadell J., Jackson R.B., Ehleringer J.R., Mooney H.A., Sala O.E., Schulze E.-D., Maximum rooting depth of vegetation types at the global scale, Oecologia 108 (1996) 583-595.

[4] Cubera E., Montero M.J., Moreno G., Effect of land use on soil water dynamics in dehesas of Central-Western Spain, in: Schnabel S., Ferreira A. (Eds.), Advances in GeoEcology 37: Sustainability of Agrosilvopastoral systems - Dehesas, Montados -, Catena Verlag, Reiskirchen, 2004, pp. 109-123.

[5] David T.S., Ferreira M.I., Cohen S., Pereira J.S., David J.S., Constraints on transpiration from an evergreen oak tree in southern Portugal, Agric. For. Meteorol. 122 (2004) 193-205.

[6] De Rosnay P., Polcher J., Modelling root water uptake in a complex land surface scheme coupled to a GCM, Hydrol. Earth Syst. Sc. 2 (1998) 239-255.

[7] Díaz M., Campos P., Pulido F.J., The Spanish dehesas: a diversity in land-use and wildlife, in: Pain D.J., Pienkowski M.W. (Eds.), Farming and birds in Europe. The Common Agricultural Policy and its Implications for Bird Conservation, Academic Press, London, 1997, pp. 178-209.

[8] Eagleson P.S., Ecological optimality in water-limited natural soilvegetation systems, I. Theory and hypothesis, Water Resour. Res. 18 (1982) 325-340.

[9] Eagleson P.S., Segarra R.I., Water-limited equilibrium of savanna vegetation systems, Water Resour. Res. 21 (1985) 1483-1493.

[10] Eastham J., Rose C.W., Cameron D.M., Rance S.J., Talsma T., Charles-Edwards D.A., Tree/pasture interactions at a range of tree densities in an agroforestry experiment. II. Water uptake in relation to rooting patterns, Aust. J. Agric. Res. 41 (1990) 697-707.

[11] Feddes R.A., Hoff H., Bruen M., Dawson T., de Rosnay P., Dirmeyer P., Jackson R.B., Rabat P., Kleidon A., Lilly A., Pitman A.J., Modeling Root Water Uptake in Hydrological and Climate Models, Bull. Am. Meteorol. Soc. 82 (2001) 2797-2809.

[12] Garnier F., Berger A., Rambal S., Water balance and pattern of soil water uptake in a peach orchard, Agric. Water Manage. 11 (1986) 145-158.

[13] Geiger S.C., Vandenbeldt R.J., Manu A., Variability in the growth of Faidherbia albida: the soils connection, Soil Sci. Soc. Am. J. 58 (1994) 227-231.

[14] Gómez-Gutierrez J.M., Pérez-Fernandez M., The dehesas, silvopastoral systems in semiarid Mediterranean regions with poor soils, seasonal climate and extensive utilisation, in: Etienne M. (Ed.), Western European Silvopastoral Systems, INRA Editions, Paris, 1996, pp. 55-70.

[15] Hupet F., Lambot S., Feddes R.A., van Dam J.C., Vanclooster M., Estimation of root water uptake parameters by inverse modeling with soil water content data, Water Resour. Res. 39 (2003) 11.

[16] Infante J.M., Damesin C., Rambal S., Fernández-Alés R., Modelling leaf gas exchange in holm oak trees in southern Spain, Agric. For. Meteorol. 95 (1999) 203-223.

[17] Infante J.M., Domingo F., Fernández-Aléz R., Joffre R., Rambal S., Quercus ilex transpiration as affected by a prolonged drought period, Biol. Plant. 46 (2003) 49-55.

[18] ISSS-ISRIC-FAO, World Reference Base for Soil Resources. World Soil Resources, Reports No. 84. FAO UN, Rome, 1998.

[19] Joffre R., Rambal S., Soil water improvement by trees in the rangelands of southern Spain, Oecol. Plant. 9 (1988) 405-422. 
[20] Joffre R., Rambal S., How tree cover influences the water balance of Mediterranean rangelands, Ecology 74 (1993) 570-582.

[21] Joffre R., Leiva Morales M.J., Rambal S., Fernández Alés R., Dynamique racinaire et extraction de l'eau du sol par des graminées pérennes et annuelles méditerranéennes, Acta Oecol. Oecol. Plant. 8 (1987) 181-194.

[22] Joffre R., Rambal S., Ratte J.P., The dehesa system of southern Spain and Portugal as a natural ecosystem mimic, Agrofor. Syst. 45 (1999) 57-79.

[23] Jose S., Gillespie A.R., Seifert J.R., Biehle D.J, Defining competition vectors in temperate alley cropping system in the midwestern USA: 2. Competition for water, Agrofor. Syst. 48 (2000) 41-59.

[24] Marañón T., Plant species richness and canopy effect in the savannalike "dehesa" of SW-Spain, Ecol. Mediter. 12 (1986) 131-141.

[25] Martínez-Vilalta J., Prat E., Oliveras I., Piñol J., Hydraulic properties of roots and stems of nine woody species from a holm oak forest in NE Spain, Oecologia 133 (2002) 19-29.

[26] Mateos B., Schnabel S., Rainfall interception by holm oaks in Mediterranean open woodland, in: Garcia-Ruiz J.M., Jones J.A.A., Arnaez J. (Eds.), Environmental change and water sustainability, Consejo Superior de Investigaciones Científicas and the University of La Rioja Press, Spain, 2002, pp. 31-42.

[27] McPherson G.R., Ecology and Management of North American Savannas, University of Arizona Press, Tucson, 1997.

[28] Montero M.J., Obrador J.J., Cubera E., Moreno G., The role of Dehesa land use on tree water status in Central- Western Spain, in: Schnabel S., Ferreira A. (Eds.), Advances in Geoecology 37: Sustainability of agrosilvopastoral systems-dehesas, Montados-, Catena Verlag, Reiskirchen, Germany, 2004, pp. 125-136.

[29] Moreno G., Obrador J.J., Cubera E., Dupraz C., Fine root distribution in dehesas of central-western Spain, Plant Soil 277 (2005) $153-162$.

[30] Nunes J., Madeira M., Gazarini L., Some ecological impacts of Quercus rotundifolia trees on the understorey environment in the "montado" agrosilvopastoral system, Southern Portugal, in: Mosquera-Losada M.R., Riguero-Rodriguez A., McAdam J. (Eds.), Silvopastoralism and sustainable land management, $\mathrm{CAB}$ International, Oxfordshire, 2005, pp. 275-277.

[31] Passioura J.B., Water in the soil-plant-atmosphere continuum, in: Lange O.L, Nobel P.S., Osmond C.B., Zigler H. (Eds.), Physiology Plant Ecology, II, Springer-Verlag, New York, 1982, pp. 5-33.

[32] Peñuelas J., Lloret F., Montoya R., Severe drought effects on Mediterranean woody flora in Spain, For. Sci. 47 (2001) 214-218.

[33] Pérez-Corona M.E., García-Ciudad A., García-Criado B., VázquezAldana B., Patterns of aboveground herbage production and nutritional quality structure on semiarid grasslands, Commun. Soil Sci. Plant Anal. 26 (1995) 1323-1341.
[34] Puerto A., Rico M., Influence of tree canopy (Quercus rotundifolia Lam.) on content in surface soil water in Mediterranean grasslands, Ecology (CSSR) 8 (1989) 225-238.

[35] Rambal S., Water balance and pattern of root water uptake by a Quercus coccifera L. evergreen scrub, Oecologia 62 (1984) 18-25.

[36] Rambal S., The differential role of mechanisms for drought resistance in a Mediterranean evergreen shrub: a simulation approach, Plant Cell Environ. 16 (1993) 35-44.

[37] Reicosky D.C., Millington R.J., Kute A., Peters D.B., Patterns of water uptake and root distribution of soybeans (Glycine max) in the presence of a water table, Agron. J. 64 (1964) 292-297.

[38] Sala A., Modelling canopy gas exchange during summer drought, in: Rodá F., Retana J., Gracia C.A, Bellot J. (Eds.), Ecological Studies vol. 137, Ecology of Mediterranean evergreen oak forests, Springer, Berlin, 1999, pp. 149-159.

[39] Sala A., Tenhunen J.D., Site-specific water relations and stomatal response of Quercus ilex in a Mediterranean watershed, Tree Physiol. 14 (1994) 601-617.

[40] Savé R., Castell C., Terradas J., Gas exchange and water relations, in: Rodá F., Retana J., Gracia C.A, Bellot J. (Eds.), Ecological Studies vol. 137, Ecology of Mediterranean evergreen oak forests, Springer, Berlin, 1999, pp. 135-144.

[41] Schenk H.J., Jackson R.B., Rooting depths, lateral rood spreads and below-ground/above-ground allometries of plants in water-limited ecosystems, J. Ecol. 90 (2002) 480-494.

[42] Scholes R.J., Archer S.R., Tree-grass interactions in savannas, Annu. Rev. Ecol. Syst. 28 (1997) 517-544.

[43] Thornthwaite C.W., An approach towards a rational classification of climate, Geogr. Rev. 38 (1948) 55-89.

[44] Van Wijk M.T., Bouten W., Towards understanding tree root profiles: simulating hydrologically optimal strategies for root distribution, Hydrol. Earth Syst. Sc. 5 (2001) 629-644.

[45] Vicente M.A., Gallardo J.F., Moreno G., González M.I., Comparison of soil water-contents as measured with a neutron probe and Time Domain Reflectometry in a Mediterranean forest ('Sierra de Gata', Central Western Spain), Ann. For. Sci. 60 (2003) 185-193.

[46] Vinckle C., Granier A., Breda N., Devillez F., Evapotranspiration of a declining Quercus robur (L.) stand from 1990 to 2001. II. Daily actual evapotranspiration and soil water reserve, Ann. For. Sci. 62 (2005) 615-623.

[47] Vrugt J.A., Hopmans J.W., Šimunek J., Calibration of a two dimensional root water uptake model for a sprinkler-irrigated almond tree, Soil Sci. Soc. Am. J. 65 (2001) 1027-1037.

[48] Young A., Agroforestry for Soil Management, CAB International, Wallingford, UK, 1997. 